\title{
Vascular plant species of the floating vegetation rafts from the Río de la Plata (Argentina)
}

\author{
Especies de plantas vasculares de las balsas de vegetación flotantes \\ del Río de la Plata (Argentina)
}

\author{
Elián Leandro Guerrero ${ }^{1,2,11}$, Federico Lisandro Agnolin ${ }^{2,3,4}$, Mariana Benedictto ${ }^{5}$, Diego Gambeta ${ }^{6,7}$, \\ Felipe Andrés Suazo Lara ${ }^{8}$, María Rosa Derguy ${ }^{2,9,10}$ \& María José Apodaca ${ }^{1,2}$
}

\begin{abstract}
In South American rivers, Eichhornia crassipes and other floating plants intertwine and form floating rafts commonly known as "camalotales" which are especially abundant during flooding periods. During extraordinary floods, hectares of floating mats are drifted by the Plata Basin Rivers. In the Río de la Plata several reports suggest that many animal and plant species from subtropical latitudes colonizes the area through these large rafts. These episodes are very important from the economic point of view because they cause several troubles to navigation and other activities. On the other hand, benefits to biodiversity are conspicuous, and many authors consider this process vital to the Río de la Plata wetlands and forests. However, there is scarce knowledge about Eichhornia rafts plant species composition. With the aim of creating an exhaustive list of the flora of the Eichhornia rafts, we visited the Río de la Plata coast during a massive Eichhornia rafts arrival. Thirty-two plant species were recorded in three different plant assemblages: Eichhornia rafts sensu stricto, floating reeds (canutillares) and embalsados. In front of this unexpected we emphasize the need to include this phenomenon in regional biodiversity conservation plans.
\end{abstract}

Key words: biodiversity conservation, Eichhornia crassipes, Paraná-Plata basin, plant checklist, raft dispersal.

\section{Resumen}

En los ríos sudamericanos, Eichhornia crassipes y otras plantas flotantes se entrelazan y forman balsas flotantes conocidas comúnmente como "camalotales" especialmente abundantes durante los períodos de inundación. Durante las inundaciones, grandes superficies de estas balsas flotantes son derivadas por los ríos de la Cuenca del Plata. En el Río de la Plata numerosos trabajos sugieren que muchas especies de animales y plantas de latitudes subtropicales colonizan el área a través de estas grandes balsas. Estos episodios son muy importantes desde el punto de vista económico debido a que causan varios problemas de navegación y otras actividades. Por otro lado, para la biodiversidad tiene beneficios evidentes, y muchos autores consideran este proceso vital para los humedales y bosques del Río de la Plata. Sin embargo, hay escaso conocimiento sobre la composición de las especies de plantas de los camalotales. Con el fin de crear una lista exhaustiva de su flora, visitamos la costa del Río de la Plata durante una llegada masiva. Treinta y dos especies de plantas se registraron en tres complejos diferentes: camalotales sensu stricto, pajonales flotantes (canutillares) y embalsados. Frente a este inesperado hecho, enfatizamos la necesidad de incluir este fenómeno en los planes regionales de conservación de la biodiversidad.

Palabras claves: conservación de la biodiversidad, Eichhornia crassipes, cuenca del Paraná-Plata, relevamiento de plantas, dispersión por balsas.

\footnotetext{
${ }^{1}$ Universidad Nacional de La Plata, Facultad de Ciencias Naturales y Museo, Museo de La Plata, División Plantas Vasculares, Paseo del Bosque s/n, C.P. 1900, La Plata, Argentina.

${ }^{2}$ Consejo Nacional de Investigaciones Científicas y Técnicas (CONICET), Calle Godoy Cruz 2290, C.P. 1425, Ciudad Autónoma de Buenos Aires, Argentina.

${ }^{3}$ Museo Argentino de Ciencias Naturales “Bernardino Rivadavia”, Laboratorio de Anatomía Comparada y Evolución de los Vertebrados, Av. Ángel Gallardo 490, C.P. 1405, Ciudad Autónoma de Buenos Aires, Argentina.

${ }^{4}$ Universidad Maimónides, Fundación de Historia Natural "Félix de Azara", Calle Hidalgo 775, C.P. 1405, Ciudad Autónoma de Buenos Aires, Argentina.

${ }^{5}$ Universidad de Buenos Aires, Facultad de Ciencias Exactas y Naturales, Grupo de Estudios de Sistemas Ecológicos en Ambientes Agrícolas, Ciudad Univesitaria, C.P. 1428, Ciudad Autónoma de Buenos Aires, Argentina.

${ }^{6}$ Museo y Archivo Histórico de Mar de Ajó, Calle Lebensohn 566, B7109, Mar de Ajó, Partido de La Costa, Argentina.

${ }_{7}^{7}$ Museo Regional de Historia y Ciencias Naturales de San Clemente del Tuyú, Escuela de Bellas Artes, Av. III 3751, B7105, San Clemente del Tuyú, Partido de La Costa, Argentina.

${ }^{8}$ Universidad de Chile, Facultad de Ciencias, Laboratorio de Ontogenia y Filogenia, Calle Las Palmeras 3425, C.P. 653, Ñuñoa, Santiago, Chile.

${ }^{9}$ UNLP, Facultad de Ciencias Naturales y Museo, Laboratorio de Investigación de Sistemas Ecológicos y Ambientales, Diagonal 113 469, C.P. 1900, La Plata, Argentina.

${ }^{10}$ Universidad Nacional de Avellaneda, Departamento de Ciencias Ambientales y Turismo, Calle España 350, C.P. 1875, Avellaneda, Argentina.

${ }^{11}$ Author for correspondence: eguerrero@fcnym.unlp.edu.ar
} 


\section{Introduction}

In South American rivers, floating rafts, commonly known as camalotales or Eichhornia rafts, are especially abundant during flooding periods (Cabrera \& Willink 1973). The Eichhornia rafts, as defined by Tur (1972), are associations of floating vascular plants dominated by the camalotes, or water hyacints, Eichhornia crassipes (Mart.) Solms and E. azurea (Sw.) Kunth (Pontederiaceae), that are dragged downstream during flooding seasons. The rhizomes and intertwined roots of these plants support the weight of a wide diversity of animal species (Spegazzini 1905; Ihering 1911; Torres 1911; Burkart 1957; Cabrera 1964; Tur 1972; Katinas et al. 2013). Since E. crassipes became widespread in the tropical and subtropical rivers of the world as one of the worst invasive species, it forms analogue communities in many continents too (Lowe et al. 2004; GISD 2015). Troubles for navigation, fishing industry, and water intakes and problems associated with the ecological conditions of water bodies were reported in all its current geographical range (GISD 2015).

The Río de la Plata has got two mayor tributaries, the Paraná and the Uruguay rivers. Eichhornia assemblages are widespread along the floodplain of the Paraná River valley and its tributaries (Cabrera 1964). Cabrera (1971, 1976) considered that the camalotales are a Chacoan province community. However, wetlands and water plant communities are difficult to place into terrestrial biota based regionalizations (Neiff 2005). They are an important component of the Lower Paraguay and the Middle Paraná complexes of the Delta and islands of the Paraná and Uruguay Rivers Ecoregion (Matteucci 2012). In this area, which we consider the source of the rafts, the Eichhornia assemblages have been studied from the floristic, faunistic, and limnological point of view (see Sabattini \& Lallana 2007 and bibliography cited there). The Uruguay River doesn't allow big extensions of this community because it has got high rocky shores, so the bigger amount of floating vegetation comes from the Paraná river.

The "canutillares" and the "embalsados" are floristic associations closely related with the Eichhornia assemblages. The former, also known as floating reeds (Burkart 1957), are dominated by floating grasses (e.g., Panicum elephantipes Nees ex Trin. or Paspalum repens PJ Bergius) and are transported in the same way as the Eichhornia rafts during flooding periods (Burkart 1957; Lahitte et al. 1997). The embalsados, on the other hand, are true floating islands constituted by a thick mud mattress and plant debris retained by the roots of aquatic and terrestrial herbs, shrubs and even small trees (Burkart 1957; Cabrera 1964, 1976; Tur 1972). The embalsados require for its formation certain stability in the hydrological conditions, which is why they are found in protected places, such as lagoons, oxbow lakes, and swamps, and are rarely carried by water currents (Schulz 1961; Tur 1972). It is considered that the first stage of formation of the embalsados begins with the colonization of the camalotales by the Cyperaceae Oxycaryum cubense (Poepp. \& Kunth) Palla (Burkart 1957; Schulz 1961; Tur 1972). This species roots entraps mud forming an incipient soil that is later occupied by other marsh species (Burkart 1957).

Seasonal flooding in the basin covers the tidal plains, but there are extraordinary floods that affect large areas carrying large amounts of vegetation (Matteucci 2012). These exceptional events coincide with ENSO (El Niño-Southern Oscillation) years that bring heavy rainfall in the upper part of the basin (Schnack 2000). The massive arrival of large masses of Eichhornia rafts in the Río de la Plata during extreme flooding periods is a recurrent event, and has been repeated at least once on each decade during the twentieth century.

Despite the fact that the Eichhornia rafts movement through the rivers is a well-known phenomenon that is even published in the local newspapers because of the problems with navigation and snake-bites, the detail of the flora and fauna transported to the Río de la Plata is still very poorly known. There are isolated mentions of the transported fauna, for example Caiman latirostris (Anónimo 1905; Cabrera 1964), Pecari tajacu (Katinas et al. 2013), Panthera onca (Parish Robertson \& Parish Robertson 1838; 1843; Burmeister 1879), Hydrochoerus hydrochaeris, deers and birds (Torres 1911), Chthonerpeton indistnctum (Gudynas et al. 1988) and insects (Farina \& Cicchino 2016). Papers regarding specifically with this topic include one report on the Ophidia and Gymnophiona specimens collected during the 1905 flooding (Ihering 1911), and a work focused on the flooding of 1976 (Achaval et al. 1979). Both studies were carried out in the Uruguayan side of the Río de la Plata. Hauman (1915) briefly mentioned the plants carried by the 1905 Eichhornia rafts, and this is the sole observation in the Argentinean side of the Río de la Plata. Brief comments on the transport of plant species on Eichhornia rafts are also found in Guerrero et al. (2012) and in Katinas et al. (2013). 
Many authors consider that northern Buenos Aires province coastal biodiversity is higher than surrounding areas due to the contribution of species transported by the rafts (Spegazzini 1905; Cabrera \& Dawson 1944; Ringuelet 1955; 1961; Burkart 1957; Agostini et al. 2012; Saibene et al. 2012; Guerrero et al. 2012; Agnolin et al. 2014; Guerrero 2014), but nevertheless, as pointed above, there is scarce information about the species composition of these rafts.

At the beginning of 2016, as a result of the floods of the Río de la Plata basin, the coasts of this watercourse were affected by the massive arrival of floating vegetation. The aim of the present contribution is to report for the first time the flora dragged by the Eichhornia rafts to the Río de la Plata coast at Buenos Aires province, the volume of vegetation transported and how far it can reach in the ocean. The plant list is an elementary step in biodiversity conservation planning and it is useful to study the raft dispersal process, with applications in biogeography.

\section{Materials and Methods}

The Eichhornia rafts arrived at the Buenos Aires river coast (Fig. 1) on January 15, 2016, reaching their highest areal coverage between 5 and 10 days later. Field trips were performed in January 23 to Bernal (Quilmes district; Fig. 2a), in January 28 to the Reserva Municipal y Refugio Educativo Rivera Norte -Municipal Reserve and Natural Educative Refuge Ribera Norte- (San Isidro district) and in February 11 to the coast of Punta Lara (Ensenada district). The arrival of rafts persisted until March 2016, progressively decreasing the volume of vegetation (Fig. 2b).

Plant species were identified, photographed, observed, and recorded. When taxonomic determination was necessary, the specimens were collected and deposited in the Museo de La Plata herbarium (LP). All species were identified by us following Zuloaga et al. (2008).

In order to document the covered tranche of the Eichhornia rafts in the Atlantic Ocean, we also

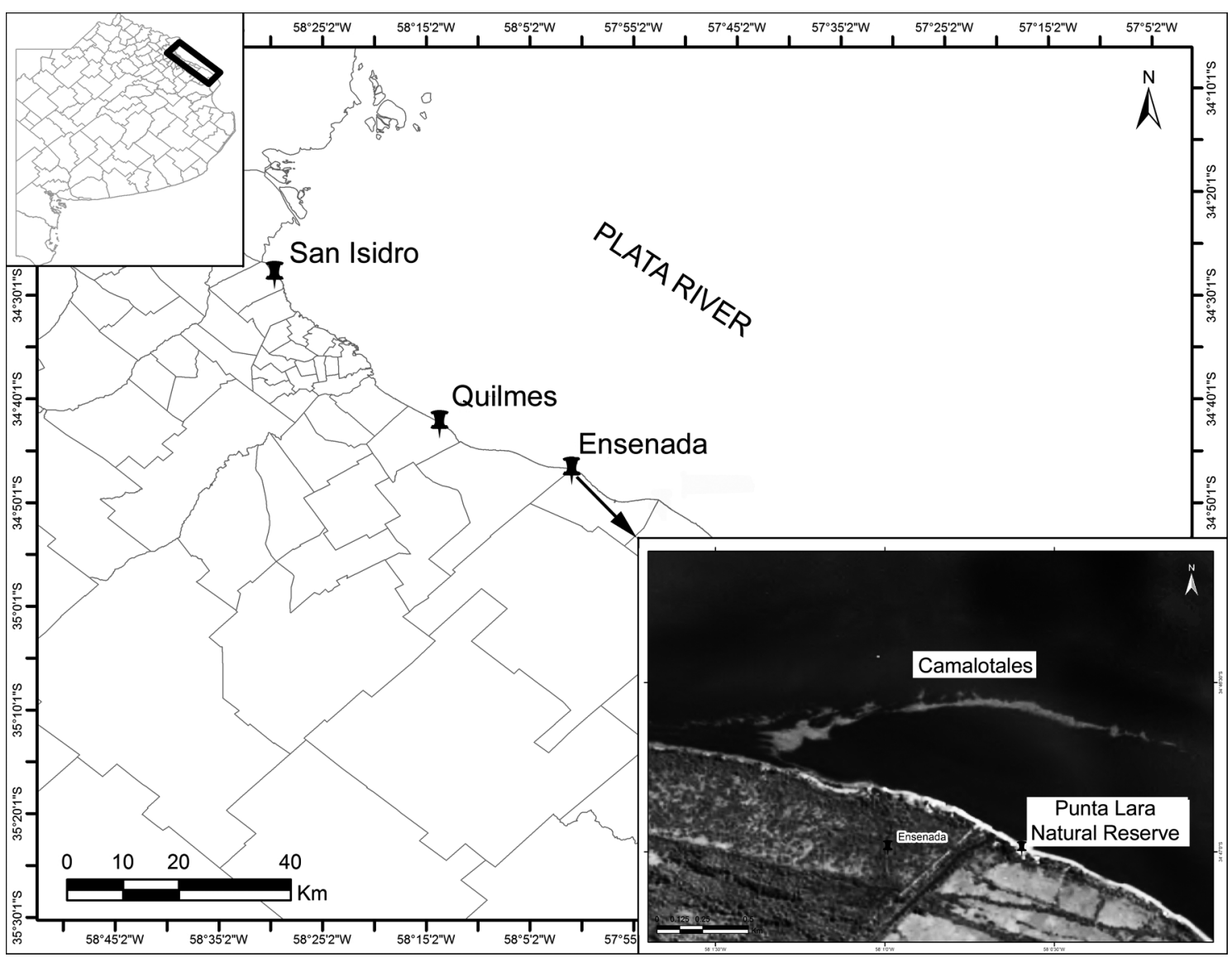

Figure 1 - Map of the study area, with a detail of a satellite image showing the Eichhornia rafts arrival. 


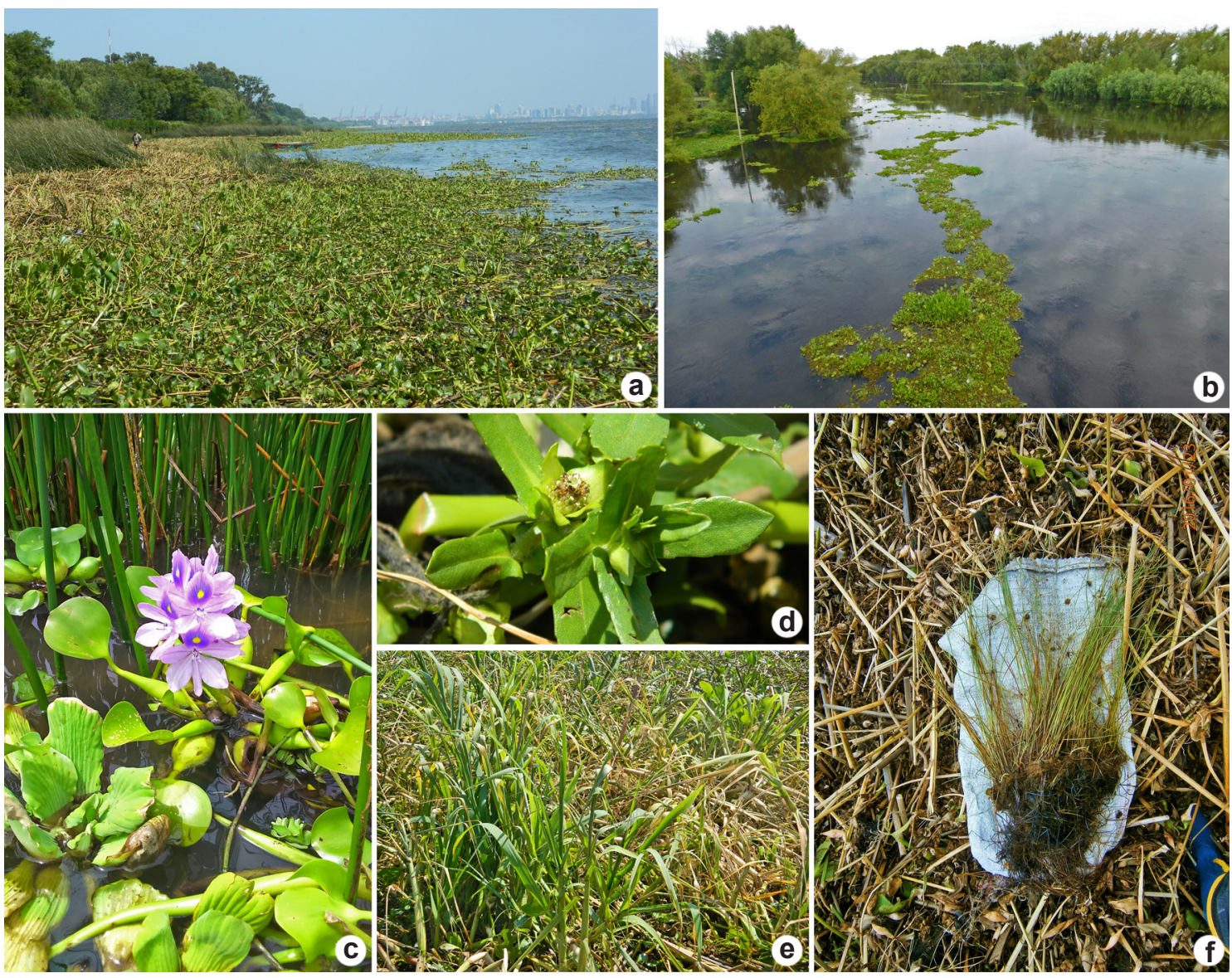

Figure 2 - Photograph of the Eichhornia rafts - a. attached to the Río de la Plata coast in Bernal; b. travelling to the Río de la Plata in the Paranacito river. Plant species of the Eichhornia rafts - c. Eichhornia crassipes; d. Enhydra anagallis; e. Panicum elephantipes, forming canutillares; f. Oxycaryum cubense forming incipient soil over the Eichhornia rafts.

added data of the vegetation that arrived to the marine Atlantic coast of the province of Buenos Aires in Punta Médanos, Mar de Ajó, and San Bernardo localities (La Costa district).

We reviewed images from the Spot satellites to evaluate the size and displacement of the floating rafts in relation to other events. These images (SPOT6_20160205 1325202 and SPOT7 20160218 1323495) were provided by the Comision Nacional de Actividades Espaciales (Argentina National Space Activities Commission, CONAE).

\section{Results}

Plant composition and associations

Thirty two species of vascular plants, dragged by the Plata river system to the northeast of the province of Buenos Aires, were recorded during the fieldwork (Tab. 1). The predominance of Eichhornia crassipes (Fig. 2c) in all the studied sites was remarkable.

In addition to most abundant floating plants, rooted coastal species such as Echinodorus grandiflorus, Gymnocoronis spilanthoides, Senecio bonariensis, Schoenoplectus californicus, and Araceae cf. Philodendron, were ripped off by the current and carried together with the camalotales.

Large sectors intermixed with the camalotal, were dominated by an association comparable to the canutillares (Fig. 2e). The plants belonging to this association in Bernal were: Panicum elephantipes as dominant, Mikania sp. and Enhydra anagallis (Fig. 2d). Floating plants of this association were mainly Salvinia biloba and Eichhornia crassipes. 
Table 1 - Vascular plants species found in the Eichhornia rafts. Hauman's list of plants (1915) was included. The only species found by Hauman (1915) but not found in this survey, is Limnobium laevigatum (Humb. \& Bonpl. ex Willd.) Heine.

\begin{tabular}{|c|c|c|}
\hline Familia & Especie & Hauman (1915) \\
\hline Alismataceae & Echinodorus grandiflorus (Cham. \& Schltdl.) Micheli & \\
\hline Apiaceae & Hydrocotyle ranunculoides $\mathrm{L}$. f. & \\
\hline Apiaceae & Lilaeopsis carolinensis J.M. Coult \& Rose & \\
\hline Araceae & Pistia stratiotes $\mathrm{L}$. & $\mathrm{x}$ \\
\hline Araceae & Araceae cf. Philodendron & \\
\hline Asteraceae & Mikania sp. & \\
\hline Asteraceae & Gymnocoronis spilanthoides (Hook. \& Arn.) DC. & \\
\hline Asteraceae & Enydra anagallis Gardner & \\
\hline Asteraceae & Senecio bonariensis Hook. \& Arn. & \\
\hline Azollaceae & Azolla filiculoides Lam. & \\
\hline Ceratophyllaceae & Ceratophyllum demersum $\mathrm{L}$. & \\
\hline Cyperaceae & Pycreus megapotamicus (Kunth.) Nees & \\
\hline Cyperaceae & Oxycaryum cubense (Poepp. \& Kunth) Palla & \\
\hline Cyperaceae & Schoenoplectus californicus (C.A. Mey.) Soják & \\
\hline Fabaceae & Aeschynomene rudis Benth. & \\
\hline Fabaceae & Aeschynomene sp. & \\
\hline Fabaceae & Fabaceae cf. Vigna & \\
\hline Haloragaceae & Myriophyllum aquaticum (Vell.) Verdc. & $\mathrm{x}$ \\
\hline Iridaceae & Iris pseudacorus L. & \\
\hline Lemnaceae & Lemna gibba $\mathrm{L}$. & $\mathrm{x}$ \\
\hline Lemnaceae & Spirodela intermedia W. Koch. & $\mathrm{x}$ \\
\hline Onagraceae & Ludwigia peploides (Kunth) P.H. Raven & \\
\hline Poaceae & Panicum elephantipes Nees ex Trin. & \\
\hline Poaceae & Paspalum repens P.J. Bergius & \\
\hline Poaceae & Poaceae indet. 1 & \\
\hline Poaceae & Poaceae indet. 2 & \\
\hline Polygonaceae & Polygonum acuminatum Kunth. & \\
\hline Polygonaceae & Polygonum sp. & \\
\hline Pontederiaceae & Eichhornia crassipes (Mart.) Solms & $\mathrm{x}$ \\
\hline Pontederiaceae & Eichhornia azurea (Sw.) Kunth & $\mathrm{x}$ \\
\hline Pontederiaceae & Pontederia rotundifolia $\mathrm{L}$. f. & $\mathrm{x}$ \\
\hline Salviniaceae & Salvinia biloba Raddi & $\mathrm{x}$ \\
\hline Salviniaceae & S. minima Baker & \\
\hline
\end{tabular}

We also found rooted species forming embalsados in Bernal with portions of soil of approximately $0.2 \mathrm{~m}$ diameter and $30 \mathrm{~cm}$. thick, formed by silt and rest of plants in decomposition intertwined by the roots. They supported the following plants: Salvinia biloba, Azolla filiculoides,
Oxycaryum cubense, Pycreus megapotamicus, Poaceae indet., Pontederia rotundifolia, Polygonum sp., Hydrocotyle ranunculoides, Lilaeopsis carolinensis, Aeschynomene rudis and Aeschynomene sp. and Fabaceae $c f$. Vigna sp. There were other rests composed of Oxycaryum cubense 
and Salvinia biloba, with a lower soil development (Fig. 2f), that might be interpreted as the primary stage of embalsados formation according to previous authors (Burkart 1957; Schulz 1961; Tur 1972).

We also found many tree branches, trunks, tables, expanded polyethylene, bottles and other plastic residues. Anecdotally we also found an onion (Allium cepa L.) coincidently with Achaval et al. (1979) observations.

\section{Size}

Satellite images allowed us to detect an almost linear raft near Reserva Natural Punta Lara (Fig. 1) which had a total length that exceeded 2 $\mathrm{km}$. Unfortunately, there are no clear images of the maximum peaks of floating plant invasion, because the sky was cloudy. As seen in the satellite images (Fig. 1) and from the coast (Fig. 2a), the Eichhornia rafts maintained a linear and meandering form, like the form they had while they travel inside Paraná Delta water courses (Fig. 2b). Figures 1 illustrate the arrival of vegetation by satellite images in the area of Punta Lara and Figure $2 \mathrm{~b}$ shows the displacement of the Eichhornia rafts along the Paranacito River.

\section{Distance reached}

As the rafts travelled to the south and surpassed the mouth of the Rio de la Plata, part of them arrived to the maritime Atlantic coast of the province of Buenos Aires. From the mouth of the Río de la Plata to the places where they were found, the plants must have travelled at least 50-70 $\mathrm{km}$. The plants deposited in the coast by the sea currents were in different degrees of disintegration, for example: Salvinia biloba, Pistia stratiotes, Eichornia crassipes, E. azurea, Schoenoplectus californicus, and Myriophyllum aquaticum. In addition, trunks, branches, rhizomes and palm leaves were also deposited in the coast.

\section{Discussion}

The list of plants recorded in the last flooding event of January 2016 analyzed here by far exceeds the number of species previously reported by Hauman (1915) and Achaval et al. (1979). As mentioned by these authors, Eichhornia rafts studied were dominated by Eichhornia crassipes. Plant species richness was higher than expected based on previous works, and even more important, we found that not only floating plants were transported, but also rooted herbs, climbers and small bushes.
The transport of embalsados along the Paraná River had already been noted by Tur (1972) for the Santa Fe Island area, upstream from where the Paraná Delta begins. Some authors, like Burkart (1957), believed that these floating islands did not reach the Río de la Plata; therefore, this contribution is the first report of embalsados reaching the southern areas of the basin. The embalsados observed in Bernal are similar to those described for Santa Fe (Tur 1972), because unlike those of northern Argentina (Burkart 1957; Schulz 1961), lack several plant families such as Eriocaulaceae, Orchidaceae, and Dryopteridaceae.

The cloudy conditions during the months when Eichhornia rafts invaded the Río de la Plata and the resolution of the used remote sensors made it difficult to estimate the size of the plant cover. However, with other estimates, Dogliotti et al. (2016) were able to detect many patches with different size, reaching $100 \mathrm{~km}^{2}$ maximum approximate.

We cannot infer the distance travelled by the Eichhornia rafts into the Atlantic Ocean because we do not know the exact route they followed, but with the information that we recovered it is worth mentioning that the rafts dispersed propagules to more than $50-70 \mathrm{~km}$. to the Atlantic coast. Agnolin et al. (2016) mentions some legume seeds and insects discharged by the Río de la Plata to the Atlantic coast of Buenos Aires with floating plant residues. Also Farina \& Cicchino (2016) found some beetles (Carabidae) and other insects over the rests of Eichhornia rafts in Mar del Tuyú, $35 \mathrm{~km}$. far from the Río de la Plata mouth. That is remarkable and leads to the hypothesis that possibly some subtropical species colonized the Buenos Aires sea coast by these means (Agnolin et al 2016).

\section{Conclusions}

This is the first study that analyzed the Eichhornia rafts in the Argentinean coast of the Río de la Plata from a taxonomical point of view and must be considered a first step to face this phenomenon from the biogeographical and biodiversity conservation point of view.

Thirty-two vascular plant species dragged by the Paraná-Plata fluvial system to northeastern Buenos Aires province were recorded. In addition to the typical Eichhornia rafts, we observed the presence of canutillares and embalsados, as well as rooted plants, trunks and many residues which also contributed to the passive drag of riparian biota. 
The importance of Eichhornia rafts in passive dispersal was inferred by previous authors. In this survey we quantified this by the enumeration of the plant species. Passive dispersal by Eichhornia rafts has been mentioned repeatedly in the bibliography as the cause of the high biotic diversity of northeastern Buenos Aires province, as we have seen in the introduction. This natural process is probably essential to maintain this diversity, carrying individuals from northern populations and enriching the Río de la Plata shores with new species occasionally. Hence, the rafting dispersal mechanism deserves more attention and some conservation planning. For example, it would be useful to discuss whether it is necessary to eradicate vegetation, as some municipalities did.

\section{Acknowledgements}

We acknowledge Ana Belén Tenorio, Sergio Lucero, and the neighbors of Bernal by their help during the field-work. To Jorge Victor Crisci, Liliana Katinas and Pablo Grilli for a critical reading of a preliminary version of the manuscript. We thank Bárbara Gasparri and Willy Bryant from Ribera Norte for sharing unpublished information and for their help during fieldwork; Nicolás Chimento for the use of his photograph for Figure $2 \mathrm{~b}$; Gabriel Lio for the photograph 2c and Nieves Baldacini for the photograph $2 \mathrm{f}$. We also thank two anonymous reviewers that contributed to improve our work.

\section{References}

Achaval F, González JG, Meneghel M \& Melgarejo AR (1979) Lista comentada del material recogido en costas uruguayas, transportado por camalotes desde el Río Paraná. Acta Zoológica Lilloana 35: 195-200.

Agnolin FL, Godoy I \& Carlini P (2014) Reptiles y anfibios del delta del río Paraná en la provincia de Buenos Aires, Argentina. In: Athor J (ed.) El delta bonaerense. Naturaleza, conservación y patrimonio cultural. Fundación de Historia Natural Félix de Azara, Buenos Aires. Pp. 184-210.

Agnolin FL, Lucero S, Chimento N \& Guerrero EL (2016) Mamíferos terrestres de la costa atlántica de Buenos Aires. In: Athor J \& Celsi CE (eds.) La costa atlántica de Buenos Aires. Naturaleza y patrimonio cultural. Fundación de Historia Natural Félix de Azara, Buenos Aires. Pp. 139-180.

Agostini MG, Saibene P \& Barraso DA (2012) Anfibios de la Reserva Natural Punta Lara. In: Roesler I \& Agostini MG (eds.) Inventario de los vertebrados de la Reserva Natural Punta Lara, provincia de Buenos
Aires, Argentina. Monografía de Aves Argentinas, Buenos Aires. Pp 71-82.

Anónimo (1905) El Chaco en Buenos Aires. Semanario Caras y Caretas 8: 56.

Burkart AE (1957) Ojeada sinóptica sobre la vegetación del delta del río Paraná. Darwiniana 11: 457-561.

Burmeister H (1879) Description physique de la République Argentine d'après des observations personelles et étrangères. Tome troisième, animaux vertébrés. Imprenta Coni, Buenos Aires. 555p.

Cabrera AL (1964) Las plantas acuáticas. Eudeba, Buenos Aires. 93p.

Cabrera AL (1976) Regiones fitogeográficas argentinas. Tomo II. In: Parodi LR (dir) Enciclopedia argentina de agricultura y jardineria. ACME S.A.C.I., Buenos Aires. Pp. 1-85.

Cabrera AL \& Dawson G (1944) La selva marginal de Punta Lara en la ribera argentina del Río de La Plata. Revista del Museo La Plata, Botánica 22: 167-305.

Cabrera AL \& Willink A(1973) Biogeografía de América Latina. Serie Biología, Monografía 13. Organización de los Estados Americanos, Washington. 120p.

Dogliotti AI, Gossn JI, Vanhellemont Q \& Ruddick K (2016) Large invasion of floating aquatic plants in the Río de la Plata estuary! Ocean Optics XIII Conference, Victoria. Pp. 1-10.

Farina JL \& Cicchino AC (2016) Una excursión entomológica por la costa atlántica bonaerense. In: Athor J \& Celsi CE (eds.) La costa atlántica de Buenos Aires. Naturaleza y patrimonio cultural. Fundación de Historia Natural Félix de Azara, Buenos Aires. Pp. 281-323.

GISD - Global Invasive Species Database (2015). Species profile Eichhornia crassipes. Available at $<$ http://www.iucngisd.org/gisd/species.php?sc=70> Access on 5 April 2017.

Gudynas E, Williams J \& Azpelicueta MM (1988) Morphology, ecology and biogeography of the South American Caecilian Chthonerpeton indistinctum (Amphibia: Gymnophiona: Typhlonectidae). Zoologische Mededeelingen 62: 5-28.

Guerrero EL (2014) Modificaciones recientes en la distribución geográfica de Opiliones (Arachnida) Mesopotámicos en la provincia de Buenos Aires, Argentina, y su relación con el cambio climático. Historia Natural. 4: 85-104.

Guerrero EL, Suazo Lara F, Chimento NR, Buet Costantino F \& Simón P (2012) Relevamiento biótico de la costa rioplatense de los partidos de Quilmes y Avellaneda (Buenos Aires, Argentina). Parte I: Aspectos ambientales, botánicos y fauna de Opiliones (Arachnida), Mygalomorphae (Arachnida) y Chilopoda (Miriapoda). Historia Natural 2: 31-56

Hauman L (1915) Note sur Hydromystria stolonisfera Mey. Anales del Museo Nacional de Historia Natural 27: 325-331. 
Ihering R (1911) Cobras e amphibios das ilhotas de Aguapé. Revista do Museu Paulista 8: 454-461.

Katinas L, Crisci JV, Hoch P, Tellería MC \& Apodaca MJ (2013) Trans-oceanic dispersal and evolution of early composites (Asteraceae). Perspectives Plant Ecology Evolution Systematics 15: 269-280.

Lahitte HB, Hurrell JA, Belgrano ML, Jankowski LS, Mehltreter K, Haloua MP \& Canda G (1997) Plantas de la costa. LOLA, Buenos Aires. 200p.

Lowe S, Browne M, Boudjelas S \& De Poorter M (2004) 100 of the world's worst invasive alien species. A selection from the Global Invasive Species Database. Invasive Species Specialist Group (ISSG), Auckland. 12p.

Matteucci SD (2012) Ecorregión delta e islas de los ríos Paraná y Uruguay. In: Morello J, Matteucci SD, Rodríguez AF \& Silva ME (eds.) Ecorregiones y complejos ecosistémicos de Argentina. Orientación Gráfica Editora, Buenos Aires. Pp. 447-488.

Neiff JJ (2001) Humedales de la Argentina: sinopsis, problemas y perspectivas futuras. In: Fernandez Cirelli A (ed.) El agua en Iberoamérica. Funciones de los humedales, calidad de vida y agua segura. CYTED, Buenos Aires. Pp. 83-112.

Parish Robertson J \& Parish Robertson W (1838) Letters on Paraguay; comprising an account of a four years residence in that republic, under the government of the dictator Francia. Vol. I. John Murray, London. 359 p.

Parish Robertson J \& Parish Robertson W (1843) Letters on South America; comprising travels on the Banks of the Paraná and Río de La Plata. Vol. III. John Murray, London. 345p.
Ringuelet RA (1955) Panorama zoogeográfico de la Provincia de Buenos Aires. Notas del Museo de La Plata, Zoología 18: 1-15.

Ringuelet RA (1961) Rasgos fundamentales de la zoogeografía de la Argentina. Physis 22: 151-170.

Sabattini RA \& Lallana VH (2007) Aquatic macrophytes. In: Iriondo MH, Paggi JC \& Parma MJ (eds.) The middle Paraná river. Limnology of a Subtropical Wetland. Springer, Berlin, Heidelberg. Pp. 205-226

Saibene PE, Cajade R, Pagano LG \& Herrera R (2012) Reptiles de la Reserva Natural Punta Lara. In: Roesler I \& Agostini MG (eds.) Inventario de los vertebrados de la Reserva Natural Punta Lara, provincia de Buenos Aires, Argentina. Monografía de Aves Argentinas, Buenos Aires. Pp. 83-96.

Schnack EJ (2000) El niño en el Plata. Revista Museo 14: 71-76.

Schulz AG (1961) Notas sobre la vegetación acuática chaqueña. Esteros y "embalsados". Boletín de la Sociedad Argentina de Botánica 9: 141-150.

Spegazzini CL (1905) Flora de la provincia de Buenos Aires. Tomo I. Ministerio de Agricultura, sección de Biología Vegetal, Buenos Aires. 162p.

Torres LM (1911) Los primitivos habitantes del delta del Paraná. Imprenta de Coni Hermanos, Buenos Aires. 616 .

Tur NM (1972) “Embalsados” y “camalotales” de la región isleña del Paraná Medio. Darwiniana 17: 397-407.

Zuloaga F, Morrone O \& Belgrano M (eds.) (2008) Catálogo de las plantas vasculares del Cono Sur (Argentina, sur de Brasil, Chile, Paraguay y Uruguay). Vols. 1-3. Monographs in Systematic Botany from the Missouri Botanical Garden, Sant Louis. 3348p. 